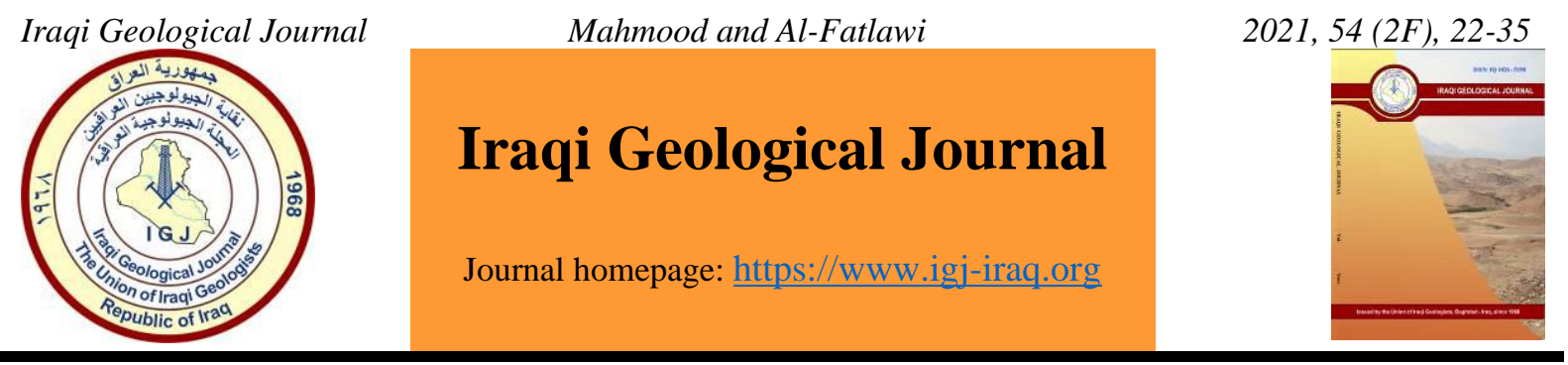

\title{
Construction of Comprehensive Geological Model for an Iraqi Oil Reservoir
}

\author{
Haider A. Mahmood ${ }^{1}$ and Omar F. Al-Fatlawi ${ }^{2,3, *}$ \\ 1 Basra Oil Company, Iraqi Ministry of Oil, Iraq \\ 2 Department of Petroleum Engineering, University of Baghdad, Baghdad, Iraq \\ 3 WASM: Minerals, Energy and Chemical Engineering, Curtin University, WA, Australia \\ * Correspondence: h.mahmood1908m@coeng.uobaghdad.edu.iq
}

Received: 30 July 2021; Accepted: 4 September 2021; Published: 31 December 2021

\begin{abstract}
The paper generates a geological model of a giant Middle East oil reservoir, the model constructed based on the field data of 161 wells. The main aim of the paper was to recognize the value of the reservoir to investigate the feasibility of working on the reservoir modeling prior to the final decision of the investment for further development of this oilfield. Well log, deviation survey, 2D/3D interpreted seismic structural maps, facies, and core test were utilized to construct the developed geological model based on comprehensive interpretation and correlation processes using the PETREL platform. The geological model mainly aims to estimate stock-tank oil initially in place of the reservoir. In addition, three scenarios were applied based on sensitivity and uncertainty of five variables to determine an accurate estimation of stock-tank oil initially in place of the reservoir. The oilwater contact appeared to be the major uncertain parameter for stock-tank oil initially in place estimation because the available geological and field data was not enough to demonstrate it confidently, and only $13 \%$ of the total wells have penetrated the water zone in the Mishrif formation. The results of all scenarios indicate that the reservoir has huge stock-tank oil initially in place. The importance of developing this oilfield is validated by its very high stock-tank oil. This is where the value of this study becomes obvious.
\end{abstract}

Keywords: Geological model; Stock-tank oil initially in place; Petrel; Middle East field

\section{Introduction}

A 3D model is a mathematical illustration developed by the special platform for any threedimensional object (Dheyauldeen et al., 2021, Al-Fatlawi et al., 2019a, Al-Fatlawi, 2018, King and Mansfield, 1997). The geological model spatially embodies the underground sediments and rocks distribution. This outcome is termed a 3D model. Normally, a model is an illustration of events or objects in the actual world. The model is considered respectable if it efficiently defines one or more real-world features related to the study (Absalyamov et al., 2020, Kolmakov and Kilyakov, 2018, Kantzas et al., 1994). In the oil industry, geological models are crucial as the first step to reservoir simulation to estimate reservoir performance under numerous hydrocarbon production cases (Kamali et al., 2013, Abeed et al., 2019, Shaker, 2020, Irby and Arps, 1964, Coats, 1969). A static model is one integrating all the geological characteristics (petrophysical, structural, lithological, etc.) of the volume of hydrocarbons stored in the underground rocks (Farmer, 2005; Awadh et al., 2012; Chafeet et al., 2020;

DOI: $\underline{10.46717 / i g j .54 .2 F .3 m s-2021-12-20}$ 
Abbas and Mahdi, 2020). The outcomes of these various steps are integrated into a 3D context, to construct a comprehensive reservoir geological model (Al-Fatlawi et al., 2017; Al-Ali et al. 2019). This model characterizes the reference setting for computing the amount of hydrocarbons in the reservoir and forms the basis for the initialization of the dynamic model (Witter et al., 2016, Lerat et al., 2007, AlFatlawi et al., 2019b).The reservoir can only be produced once; then, it is unfortunate to select a position with low development situations. The practice of geological and reservoir models allows engineers to decide which development decisions deliver the safest and most cost-efficient development plan (Bashore et al., 1993, Cavero et al., 2016, Aziz and Hussein, 2021).

The field is a Middle Eastern oil field located in the southern part of Iraq that consists of 161 wells, the field has an enormous reserve of oil about 16.3 billion STB with a relatively low API of about 22 degrees. The production of the field is estimated at depths of about $2250-2500$ meters. The initial reservoir pressure on average is around 4162 psi. Because the support of the aquifer in the field is weak, the field's drive mechanism is depletion. Therefore, numerous wells of water flooding have been activated in this field to aid in sustaining its (Al-Mimar et al., 2018; Awadh et al., 2019; Awadeesian et al., 2019; Boschetti et al., 2020). The Mishrif formation is a regionally oil-bearing suite. Within the license area it is represented by a complex of organogenic-clastic and pelitomorphic limestones of various generation. The section differentiation is observed: more compact and chalky limestones, similar to the underlying deposits of the Rumaila formation in the lower part and combination of argillaceous limestones and re-deposited reef carbonates in the upper part. Average suite thickness is $170 \mathrm{~m}$. Oil pool, which is one of the major pools in the field, is confined to the Mishrif formation and upper part of Rumaila formation. The top of the Mishrif formation is overlaid with unconformity by carbonate-terrigeneous deposits of the Khasib Formation (Awadeesian et al., 2018).

Constructing the geological model is accomplished using the following data of 161 wells

- Well-heads and its deviation survey for 161 wells.

- Well-tops from 161 wells intersecting with tops of different horizons.

- Well-logs (porosity, water saturation, net/gross, volume of shale, permeability).

- 2D/3D interpreted seismic structural maps (surfaces).

- Oil-water contact (OWC) data (surface).

- Facies (basic facies), which are characterized on the basis of lithology, sedimentology, and petrophysics.

This research aims to construct a geological model for an Iraqi reservoir with 161 wells in order to calculate the Stock-tank oil initially in place (STOIIP) under sensitivity and uncertainty analysis. This geological model can be employed in building a simulation model to best represent the reservoir behavior and simulate several scenarios considering diverse exploitation schemes and working environments to improve its depletion strategy. This study's framework covers utilizing the PETREL 2020 platform for structural modeling, gridding, petrophysical and facies modeling, variograms and Proportion Curves, sensitivity, and uncertainty analysis.

\section{Structural Model}

In order to build the structural model of the selected oilfield, the following data set is used:

- $\quad 2 \mathrm{D} / 3 \mathrm{D}$ interpreted seismic structural maps

- Well tops according to the results of the detailed correlation of the oilfield wells. Fig. 1 shows the generalized geological section of the selected oilfield.

The structural framework of the Mishrif formation model is primarily based on structural maps, derived from $2 \mathrm{D}$ seismic data. The seismic-derived surfaces were depth-adjusted to the corresponding 
well tops, identified based on core and well log data. In total, core data from 15 wells and logs from 161 wells were interpreted and correlated. This allows ensuring sufficient precision of the structural framework. Sedimentological interpretation of core and well log data resulted in recognizing of 9 main depositional cycles, that were integrated into the geological model $(\mathrm{mA} 1, \mathrm{~mA} 2, \mathrm{~mA} 3, \mathrm{mB} 1, \mathrm{mB} 2$, upper, mB2, low1, mB2, low2, Rumaila Upper, Rumaila Lower) (Fig. 2).

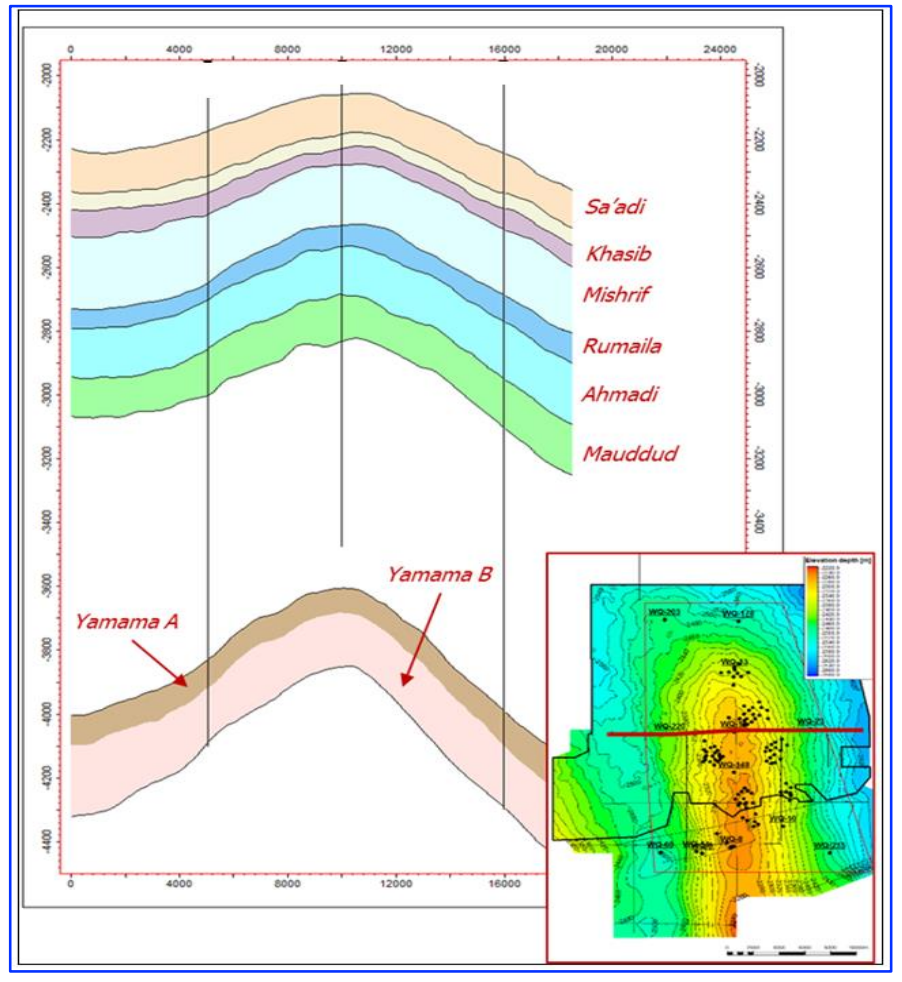

Fig. 1. Generalized geological section of the selected oilfield

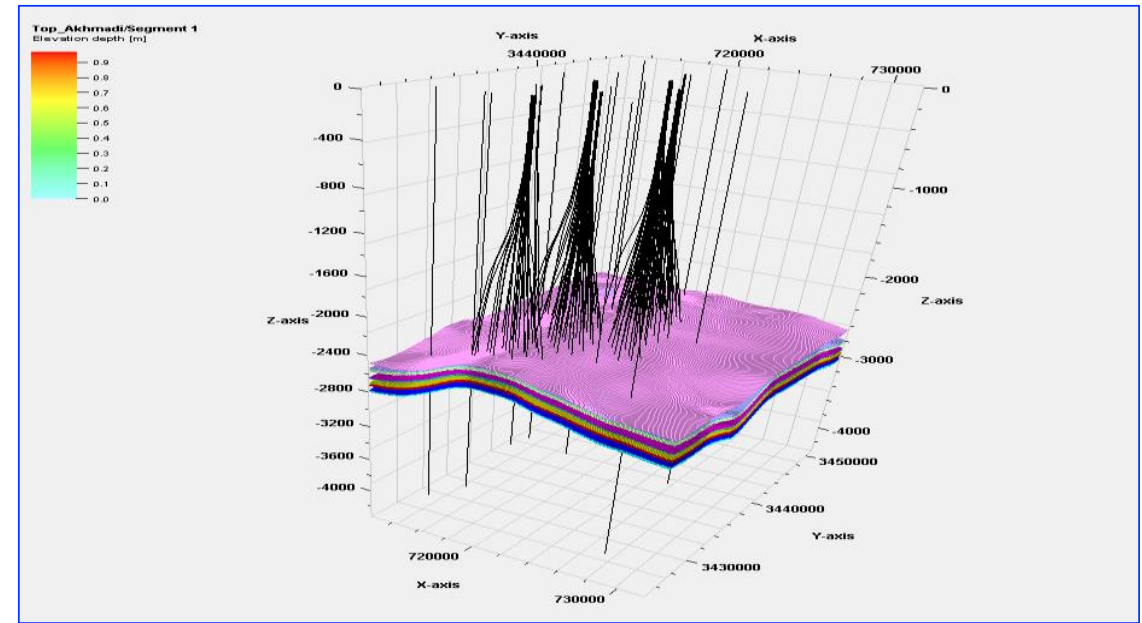

Fig. 2. Structural framework of Mishrif Formation

For structural modeling, the local B-spline algorithm has been selected as an optimal one for surface building (Fig. 3). The built surfaces have been further corrected by well tops with a moving average algorithm (Fig. 4). 


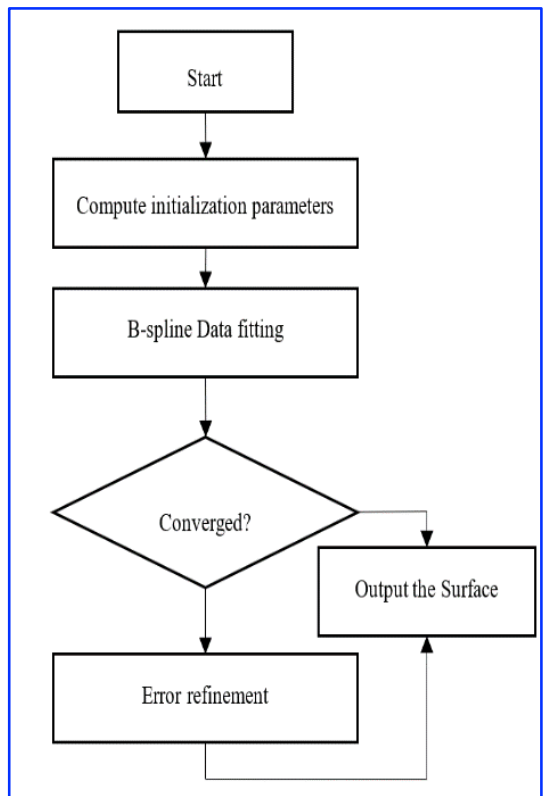

Fig. 3. Flowchart of the local Bspline algorithm

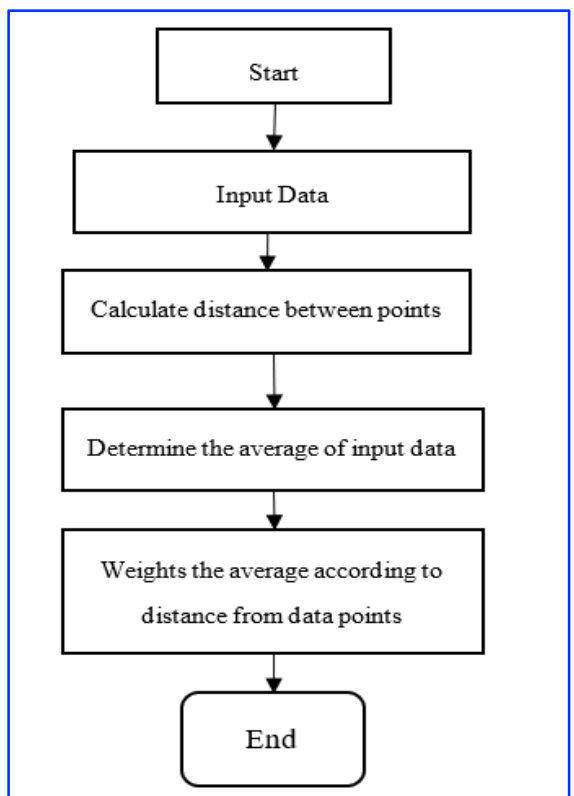

Fig. 4. Flowchart of the moving average algorithm

\subsection{Geological Gridding}

The regular Corner-point grid was used for 3D modeling. The grid cell size in $\mathrm{X}$ and $\mathrm{Y}$ directions was set to $159.1 \mathrm{~m}$ to enable $4-5$ cells between wells within 900 x $900 \mathrm{~m}$ borehole network. The average vertical size of a grid layer (Z-axis of a sell) is $1 \mathrm{~m}$. It was determined based on the minimal thickness of permeable and impermeable interlayers, heterogeneity degree, and the total thickness of formation (depositional cycles). The generalized parameters of the structural framework are shown in Table 1.

Table 1. The generalized parameters of the structural framework for Mishrif Formation

\begin{tabular}{lcccc}
\hline Formation & XYZ cell average size, $\mathbf{m}$ & Grid cells $(\mathbf{I} \times \mathbf{J})$ & Grid cells $(\mathbf{K})$ & Total cells \\
\hline Mishrif & $159.1 * 159.1 * 1$ & $152 \times 326$ & 408 & 20217216 \\
\hline
\end{tabular}

\subsection{Horizon, Zones, and Layering}

The horizons and layers of cells in zones mA distributed parallel from the bottom of the formation. This corresponds to regional transgression during the age of Mishrif. The internal geometrization of the reservoir was performed conformably and the bedding was set proportionally between the top and the bottom of each cycle. The upper sedimentation cycle was eroded. The occurrence of erosion at the top of the Mishrif reservoir was confirmed by the interpretation of well logs. Thus, 3D layering for the upper cycle is performed from the bottom. Thus, the detailed high-resolution 3D grid has been built with a resolution good enough to maintain the interlayers in the three-dimensional model. The basic parameters and visualization of the zones of Mishrif 3D grid geometry are given in Fig. 5.

\subsection{Oil Water Contact (OWC) Level Justification}

OWC levels of all formations were based on the analysis of open-hole logging, taking into consideration well testing and core studies. OWC was inherited from well logs and well tops (Fig. 6). OWC level changes from -2475.8 to -2536.5 TVDSS (Fig. 7). 


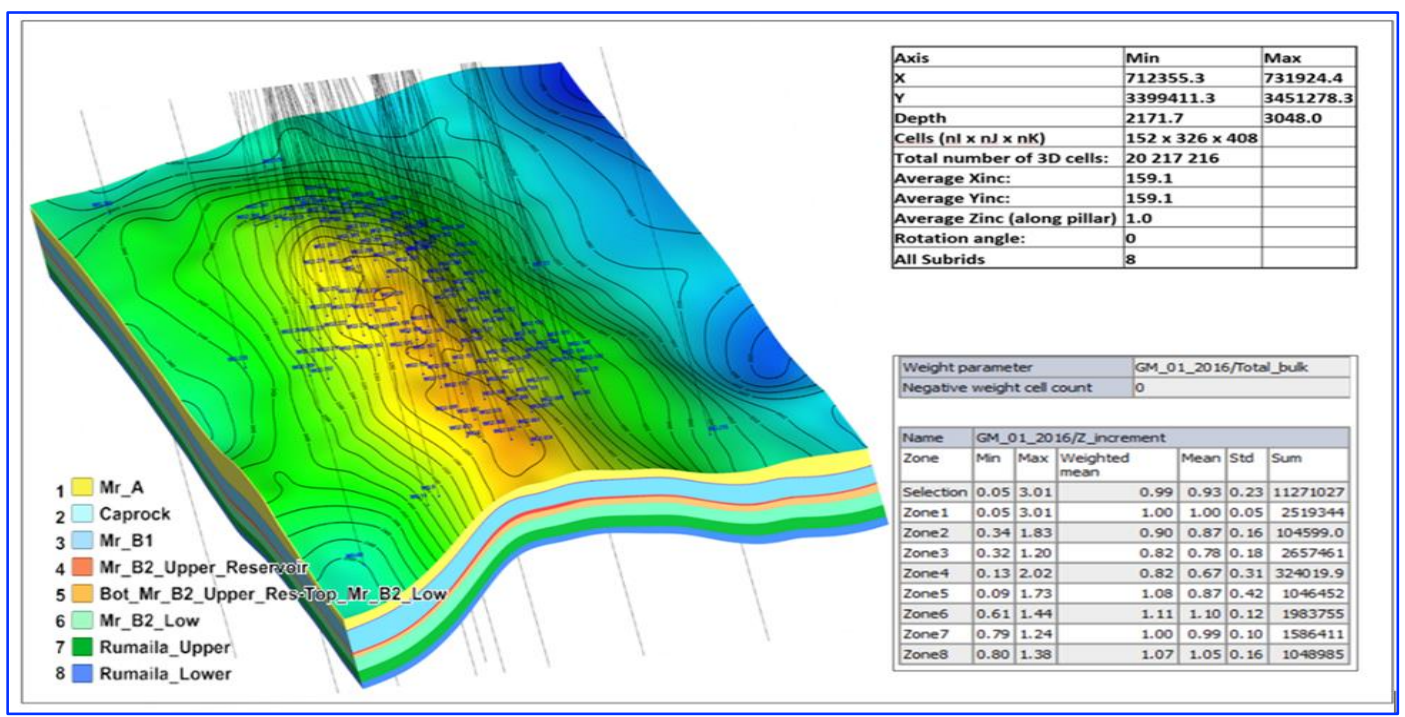

Fig. 5. Description of the geological grid parameters, Mishrif reservoir

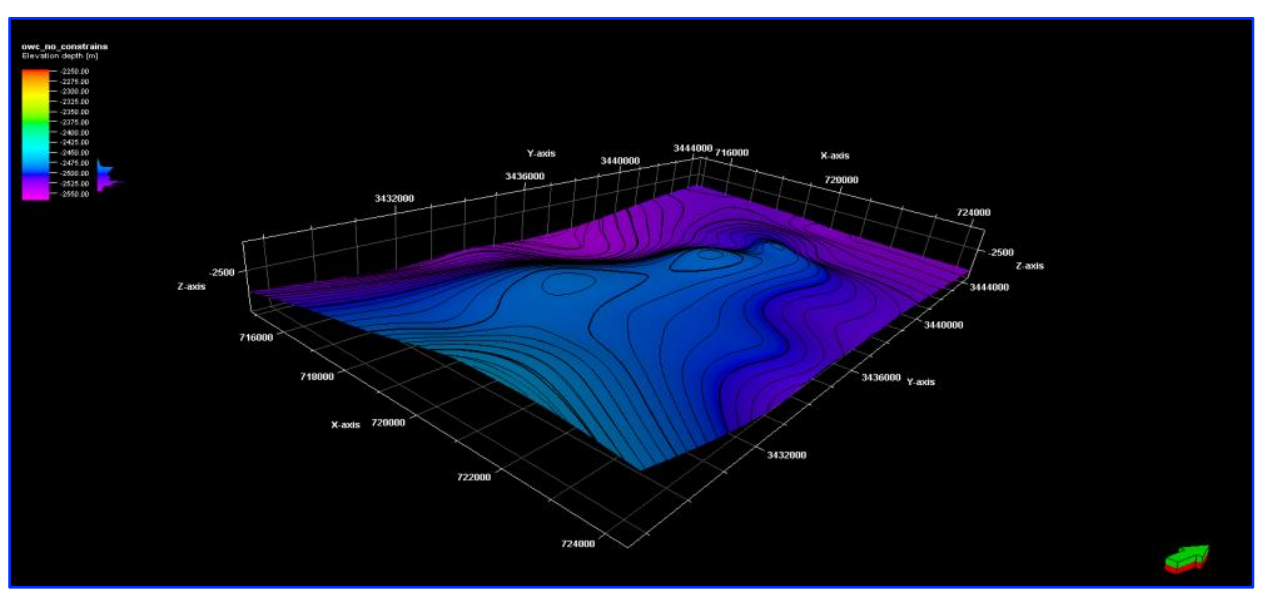

Fig.6. OWC surface in the geological model

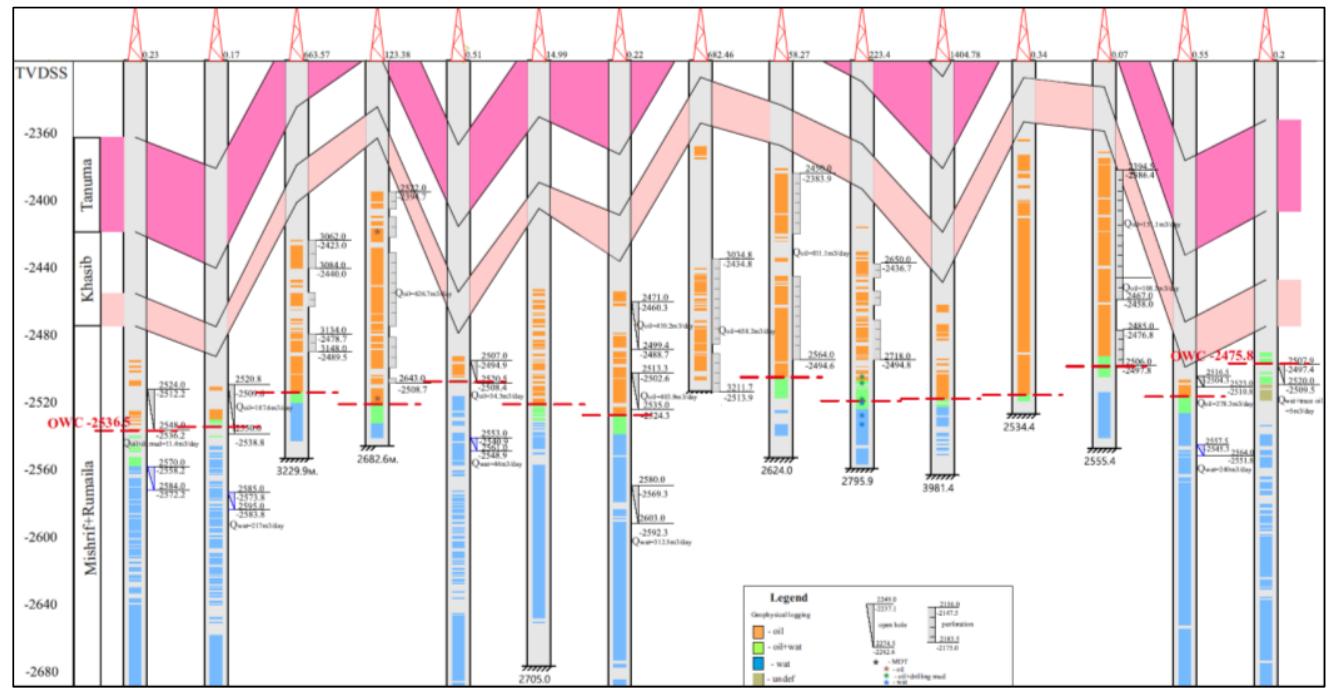

Fig. 7. Diagram of justification of oil-water contact for the Mishrif Formation 


\section{Petrophysical and Facies Modeling}

\subsection{Well Logs Upscaling}

3D grid cells that are penetrated by the well will be selected by Petrel, and then all the property values that fall into the cell will be averaged based on the method selected to generate one value for each cell as illustrated in Fig. 8.

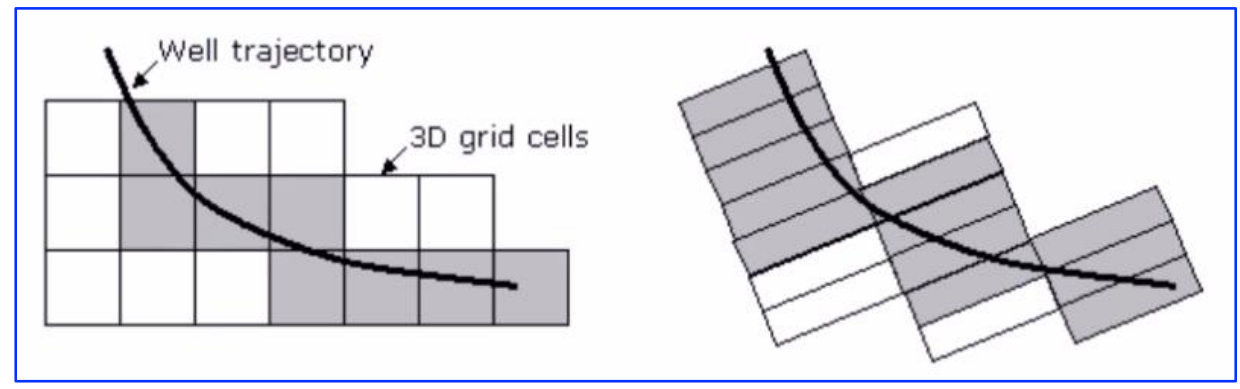

Fig. 8. Well logs upscaling process illustration

Permeability has been averaged in the well log upscaling process by the harmonic method, facies has been averaged by most of method. However, all other properties were averaged by the arithmetic method as shown in Fig. 9.

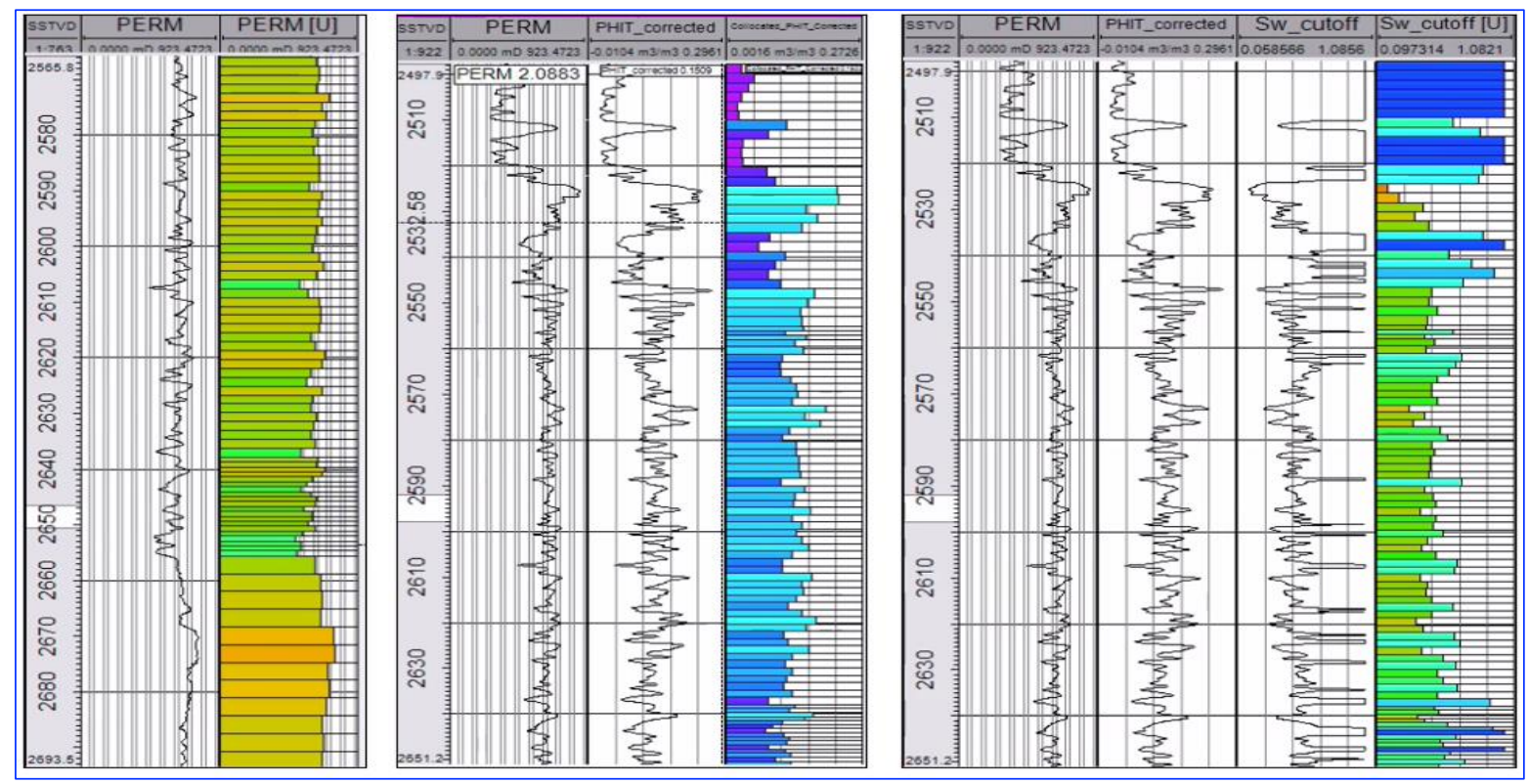

Fig. 9. Scaled up properties in a well section window

\subsection{Facies Modeling}

Fourteen rock types were distinguished within the formation based on the core studies. Integrated analysis of core and well log data enabled the merging of rock types into a much smaller number of petrotypes that can be identified from well logs:

- Petrotype I (PT-1). Bioherm/shoals.

- Petrotype II-III (PT-2/PT-3). Lagoons.

- Petrotype IV (PT- 4). Shallow-water shelf plains/Mid-ramp.

- Petrotype V (PT-5). Deepened shelf/ Distal ramp. 
Object modeling algorithm was applied for the 3D distribution of petrotype PT1. A sequent indicator simulation algorithm was used for stochastic distribution of petrotypes PT2-PT5 in the 3D model. A well-section window illustrated in Fig. 10 shows facies distributed over the length of the well for few wells as an illustration and also, horizons connecting these wells.

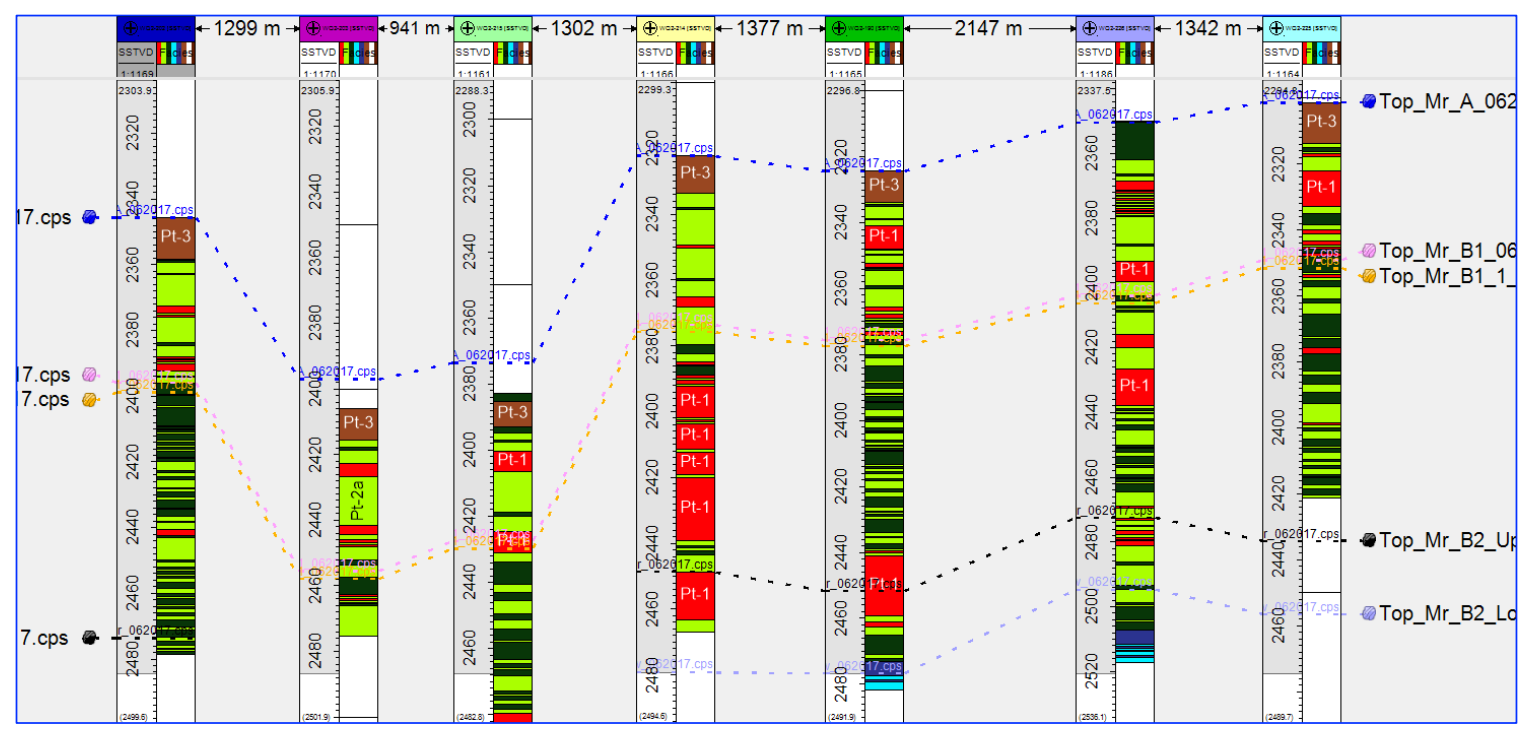

Fig. 10. Facies distribution in a well-section window

This well-section could give an insight into an approximation of the number of layers required in each horizon. Fig. 11 illustrates the distribution of facies in a 3D window.

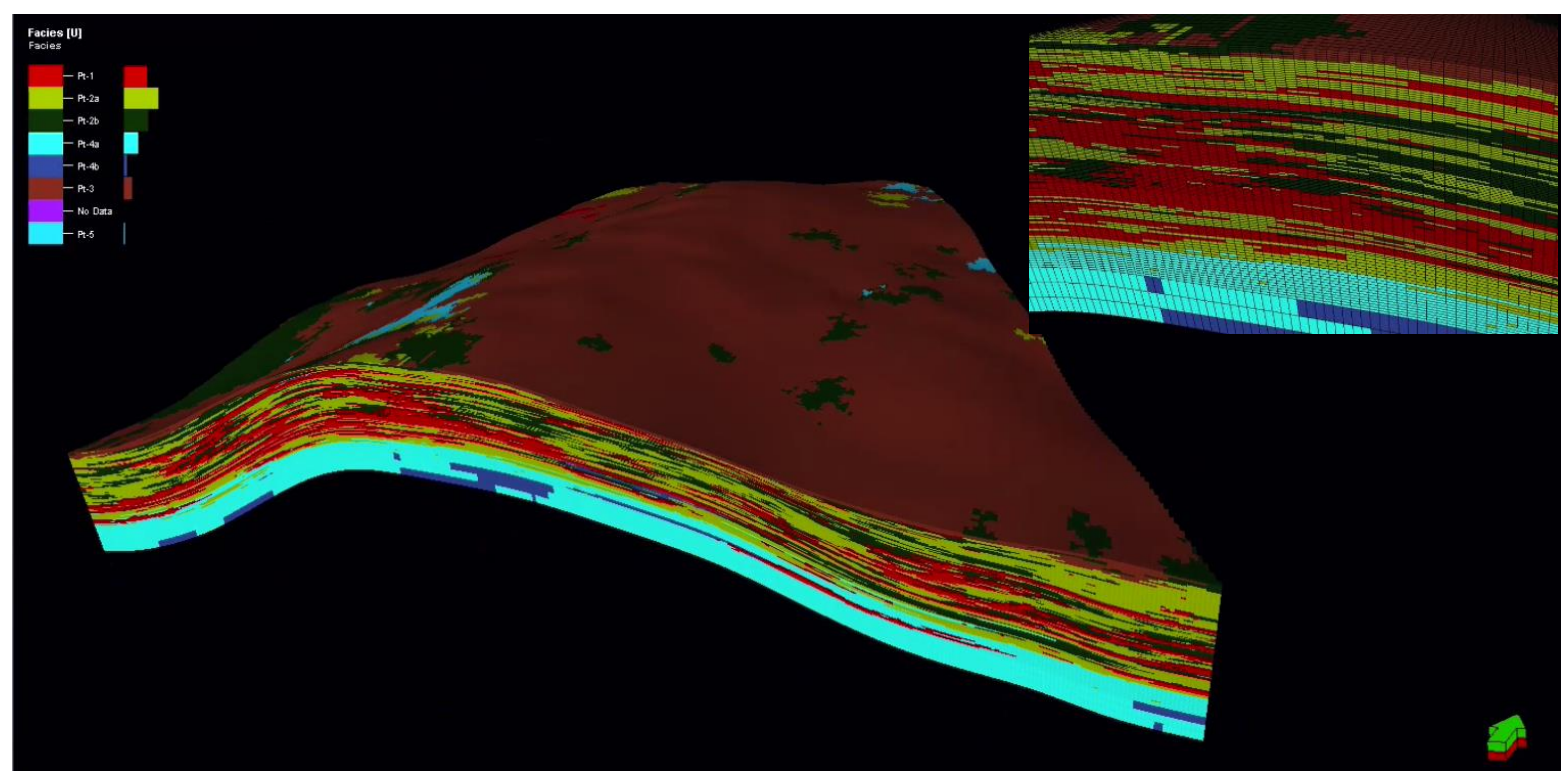

Fig. 11. Facies distribution in a $3 D$ window

\subsection{Petrophysical Modeling}

\subsubsection{Porosity modeling}

The porosity model of the Mishrif formation was built based on the results of petrophysical well $\log$ interpretation. Modeling of porosity was made using "Sequential Gaussian simulation" with data transformation by vertical and lateral probability trends (Fig. 12). 


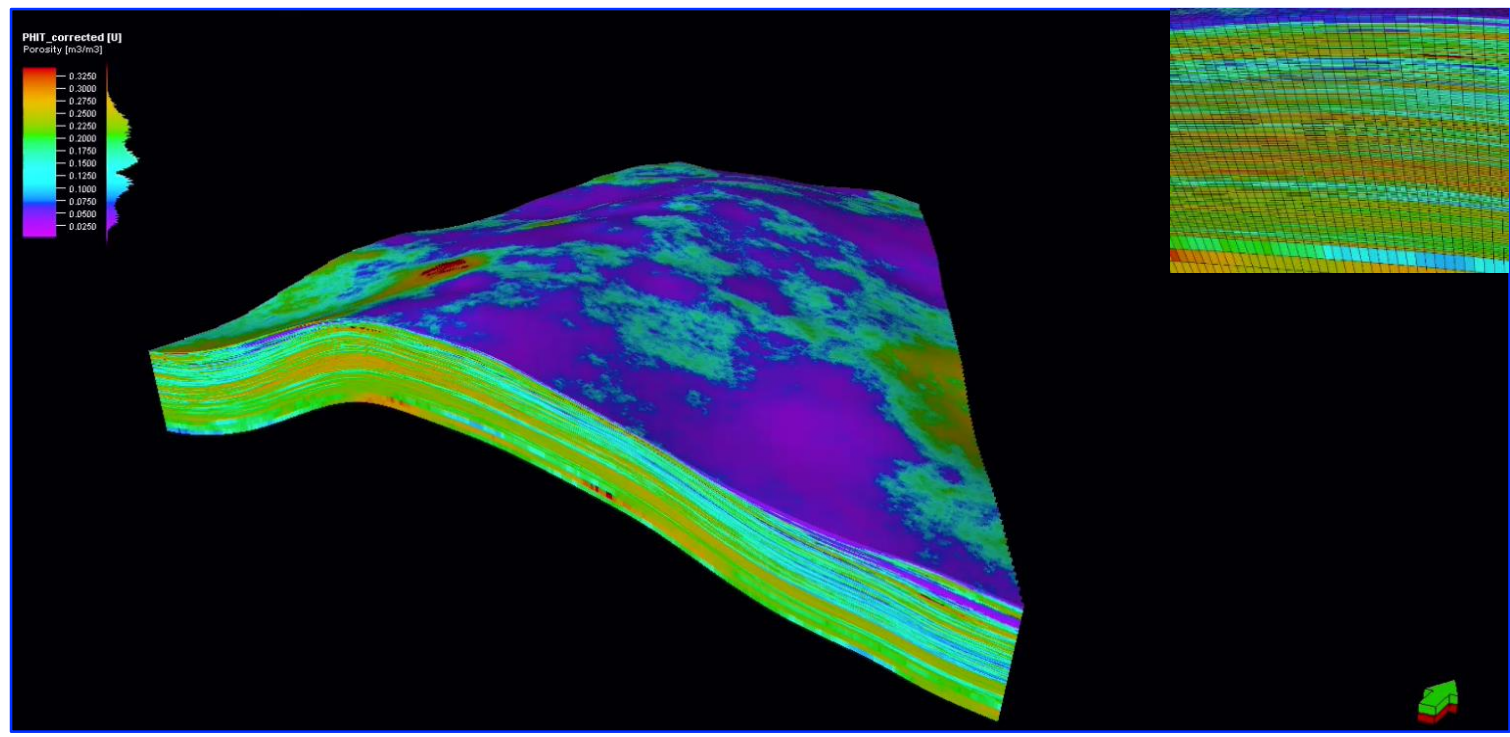

Fig. 12. 3D distribution of porosity of the Mishrif Formation

\subsubsection{Permeability modeling}

The porosity-permeability $(\varnothing-\mathrm{K})$ relationships obtained from core analysis were used for permeability calculation in the geological model. Fig. 13 shows relations $(\varnothing-K)$, separately for each pore type.

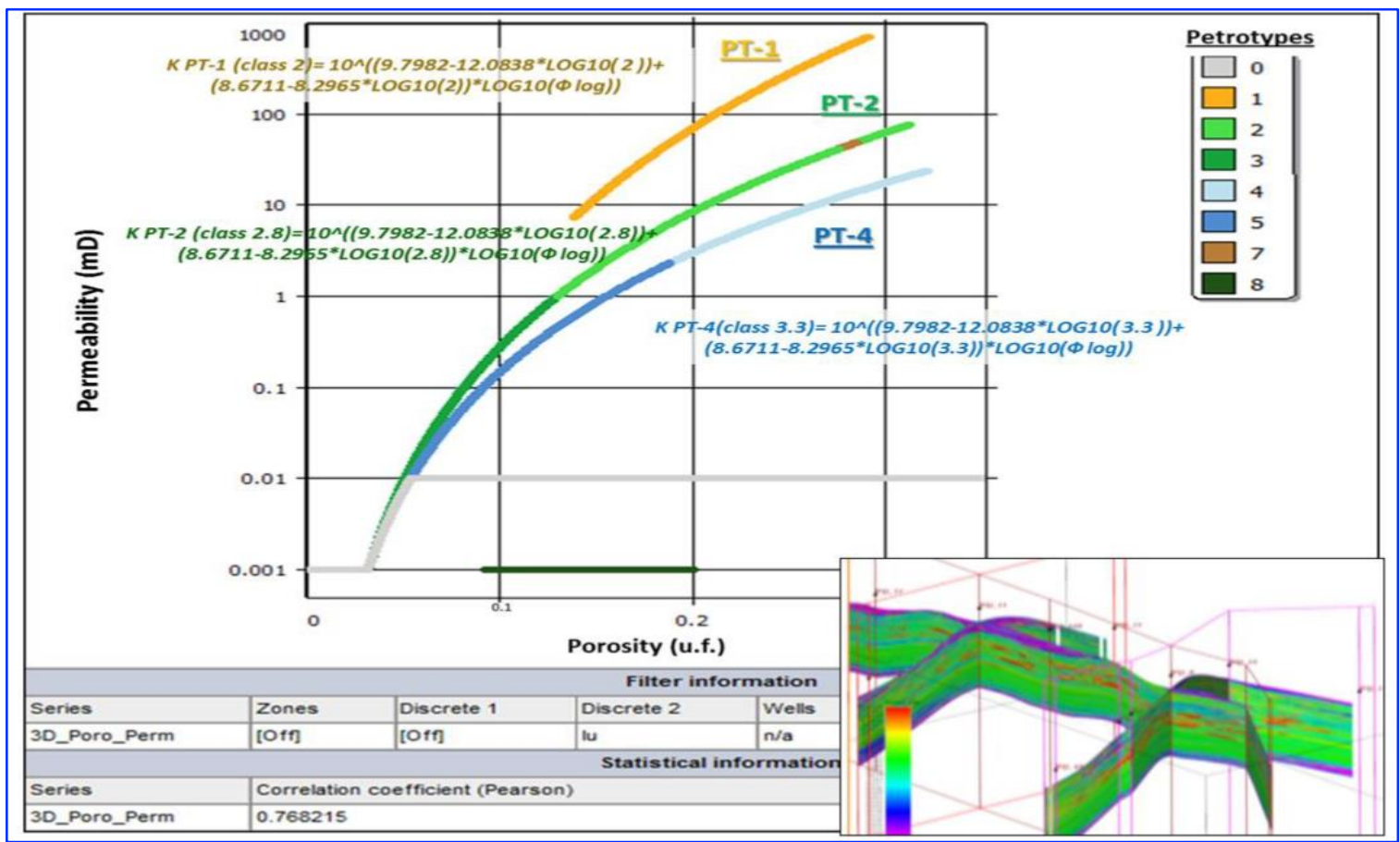

Fig. 13. Correlation between $\emptyset$ and $K$ for Mishrif reservoir

The sequential Gaussian technique was used to model the permeability, the 3D distribution is illustrated in Fig. 14. Porosity has been inserted as a secondary variable from the volume in the permeability modeling. 


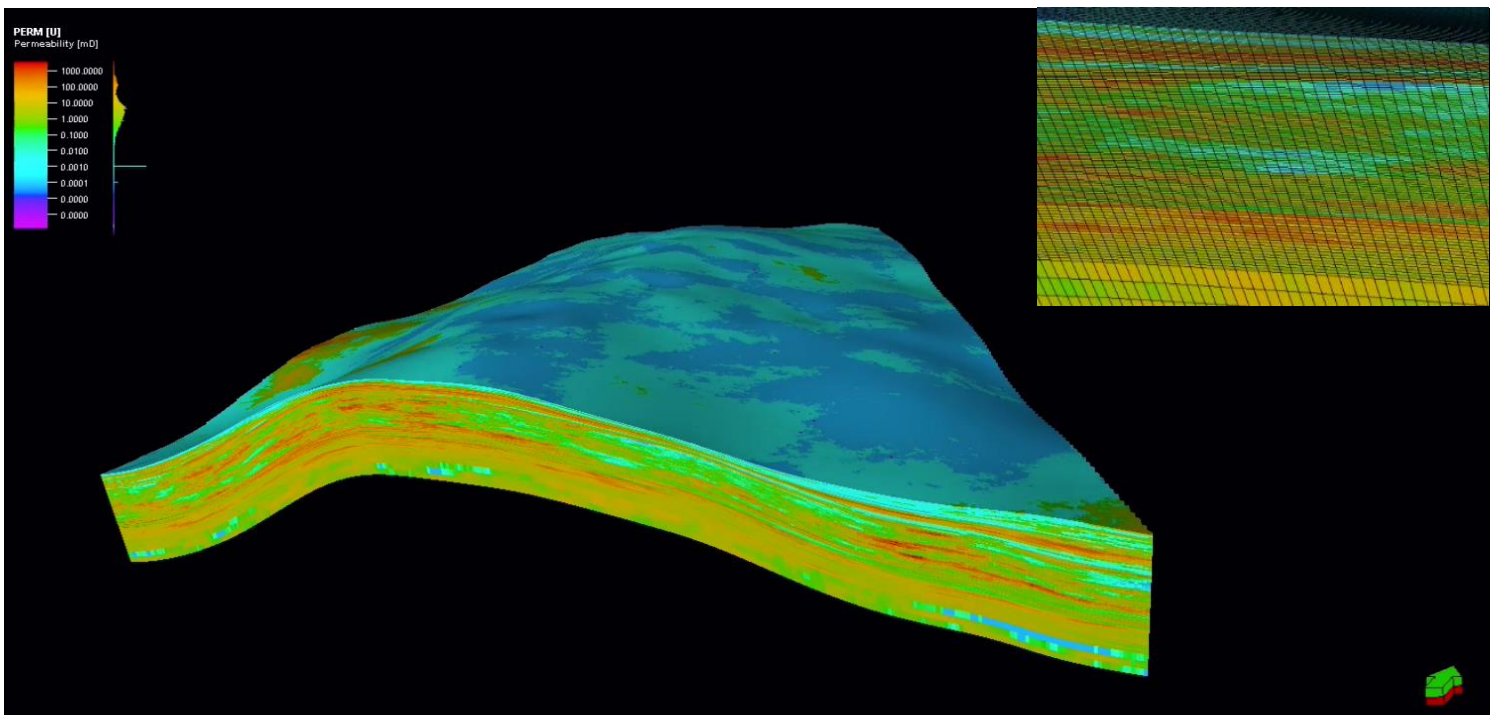

Fig. 14. 3D distribution of permeability of the Mishrif Formation

\subsubsection{Water saturation modeling}

3D distribution of water saturation is illustrated in Fig. 15. Sequential Gaussian technique was used to model the water saturation. Property modeling has been adjusted by the use of variograms and all the previous figures that illustrates the distribution of these properties represents the final distribution after vaiogram analysis.

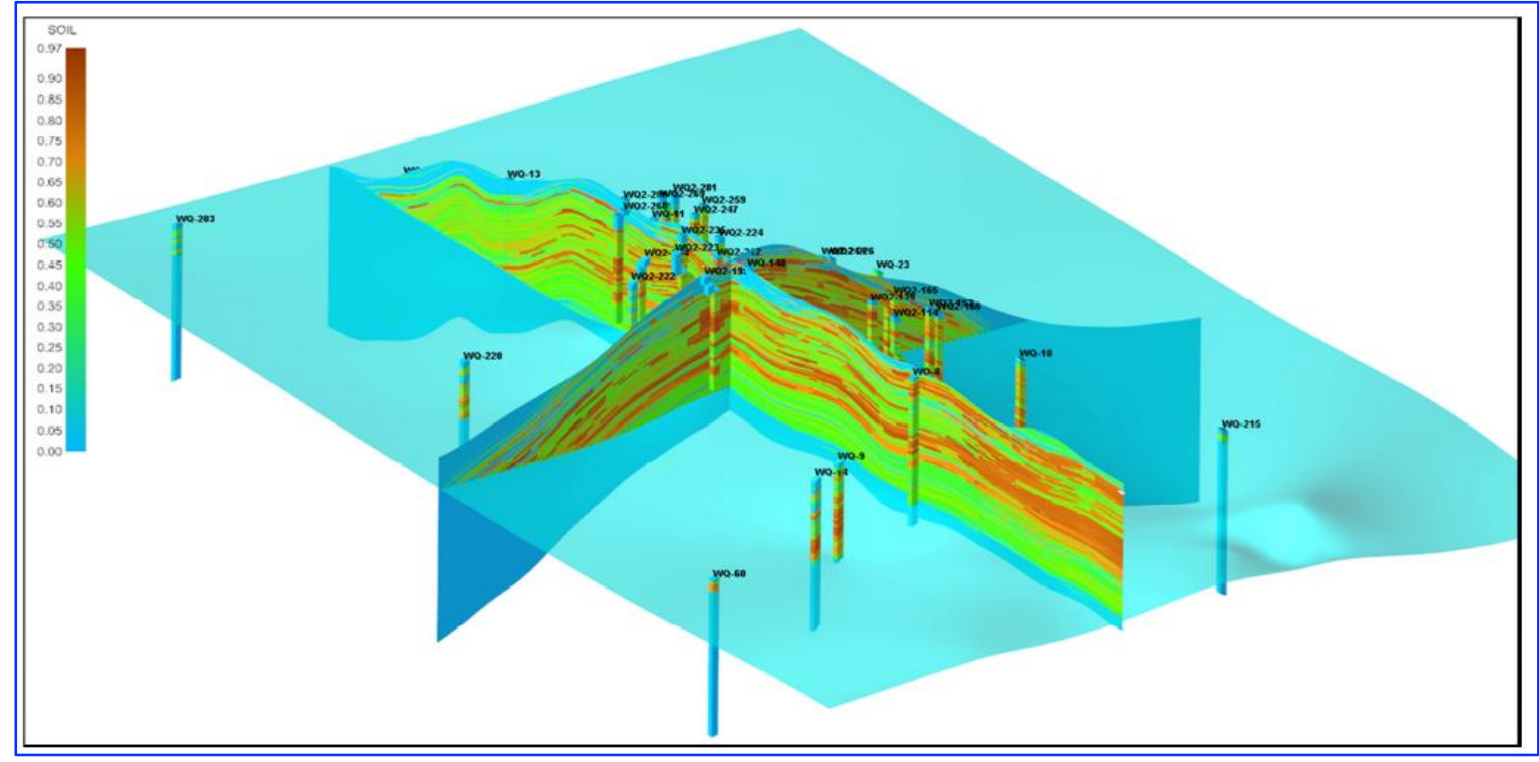

Fig. 15. 3D distribution of water saturation of the Mishrif formation

\subsection{Variogram and Proportion Curves}

A variogram is a plot of variability in terms of semi-variance against separation distance in a specific direction. This is a key parameter used by most geostatistical property modeling algorithms to describe the natural variations in the property (Pumjan and Young, 1999). Variogram analysis was employed for each property (water saturation, porosity, facies, net/gross, permeability) for each zone. 
This involves determining the directions of the variogram analysis (Vertical, Major, Minor). Calculation of the experimental variogram and creating a model variogram fitted to the experimental variogram are completed as shown in Fig. 16.

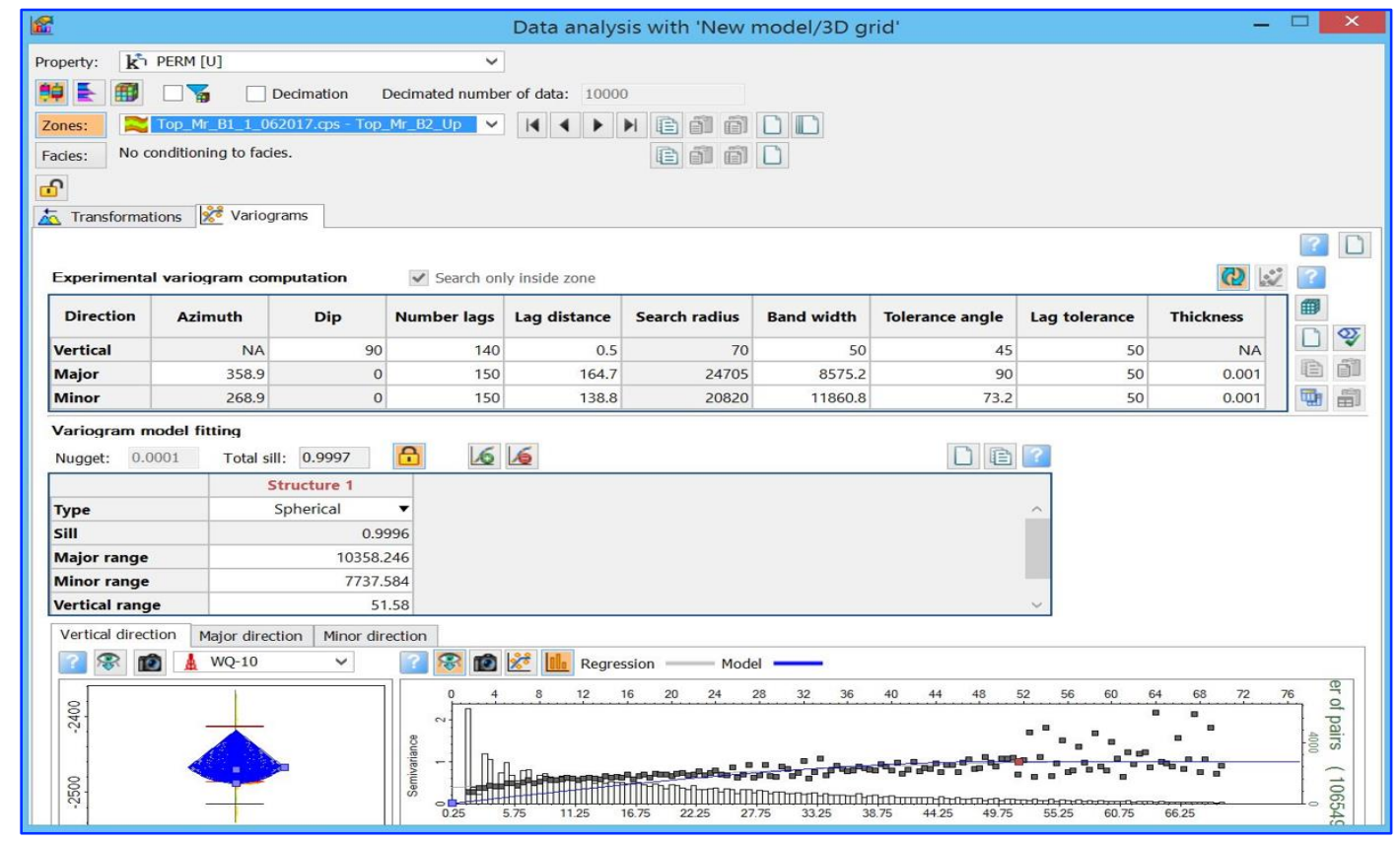

Fig. 16. Illustration of variograms analysis

\section{Results and Discussions}

\subsection{Sensitivity Analysis}

Geological and field information accumulated for the Mishrif and Rumaila formations by now corresponds to the field follow-up exploration stage. Data on 161 exploration wells and petrophysical studies allowed the determination of the in-place volumes with adequate accuracy. The drilling of production wells in the Mishrif formation proved the geological model and the STOIIP.

The most important factors regulating the oilfield development efficiency are:

- OWC surface depth

- Oil formation volume factor (Bo)

- Seed variable for water saturation (SeedSw)

- Seed variable for porosity (SeedPHI)

- Seed variable for net/gross (SeedN/G)

The global variable, SEED, is used to preserve the random nature of the value representing the start of the random number sequence for each process throughout the model. When a stochastic process is edited from the uncertainty and optimization process workflow window and its Seed check box is selected, the corresponding text box is automatically populated with the variable SEED. As with other variables, SEED will be listed in the Variables tab (Kimber et al., 2016).

Sensitivity analysis of the five variables mentioned above was carried out for the calculation of STOIIP. As is obvious from Fig. 17 that the depth of OWC is the most dominant variable to the calculation of STOIIP. OWC was selected as the main uncertain parameter for STOOIP estimation, as the available geological and field data was not enough to confidently prove it. Only 21 wells have penetrated the water zone in the Mishrif formation out of 161 wells in total, this is the reason for OWC level being the most influencing variable on the STOIIP calculations. Thus, three scenarios were 
considered to estimate the STOIIP based on different OWC levels as shown in Fig. 18. These three levels are as follows:

- Tilted OWC along the top of the water level (well log-based).

- Tilted OWC along the bottom of the oil level (well log-based).

- Horizontal OWC -2497.5 m (top elevation with water production).

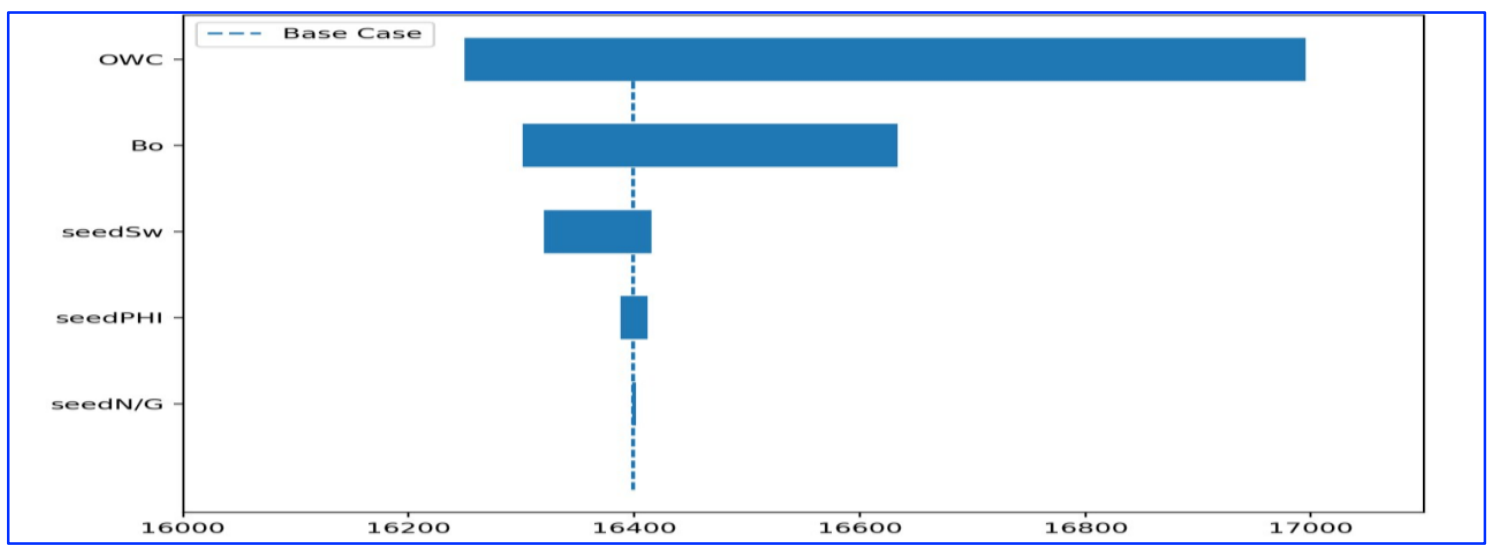

Fig. 17. Tornado chart for the illustration of sensitivity analysis

In addition, the formation volume factor (Bo) variable has a major influence, this is due to the large hydrocarbon column of 300 meters. The formation volume factors range from (1.20 to 1.24) (bbl/STB) in the Mishrif formation and (Bo) is known to vary with depth (León et al., 1995, Boukadi et al., 1999). SeedSw variable has a reasonable effect also compared to the rest of the variables, the reason behind this is that the SeedSw controls the water saturation property distribution in the 3D model and this can varies depending on the SeedSw which affects STOIIP calculations. These three variables are taken into consideration in the uncertainty analysis due to the results of the tornado chart, while the SeedPHI and SeedN/G variables were excluded from the uncertainty analysis because of their very minor impact on the STOIIP calculations.

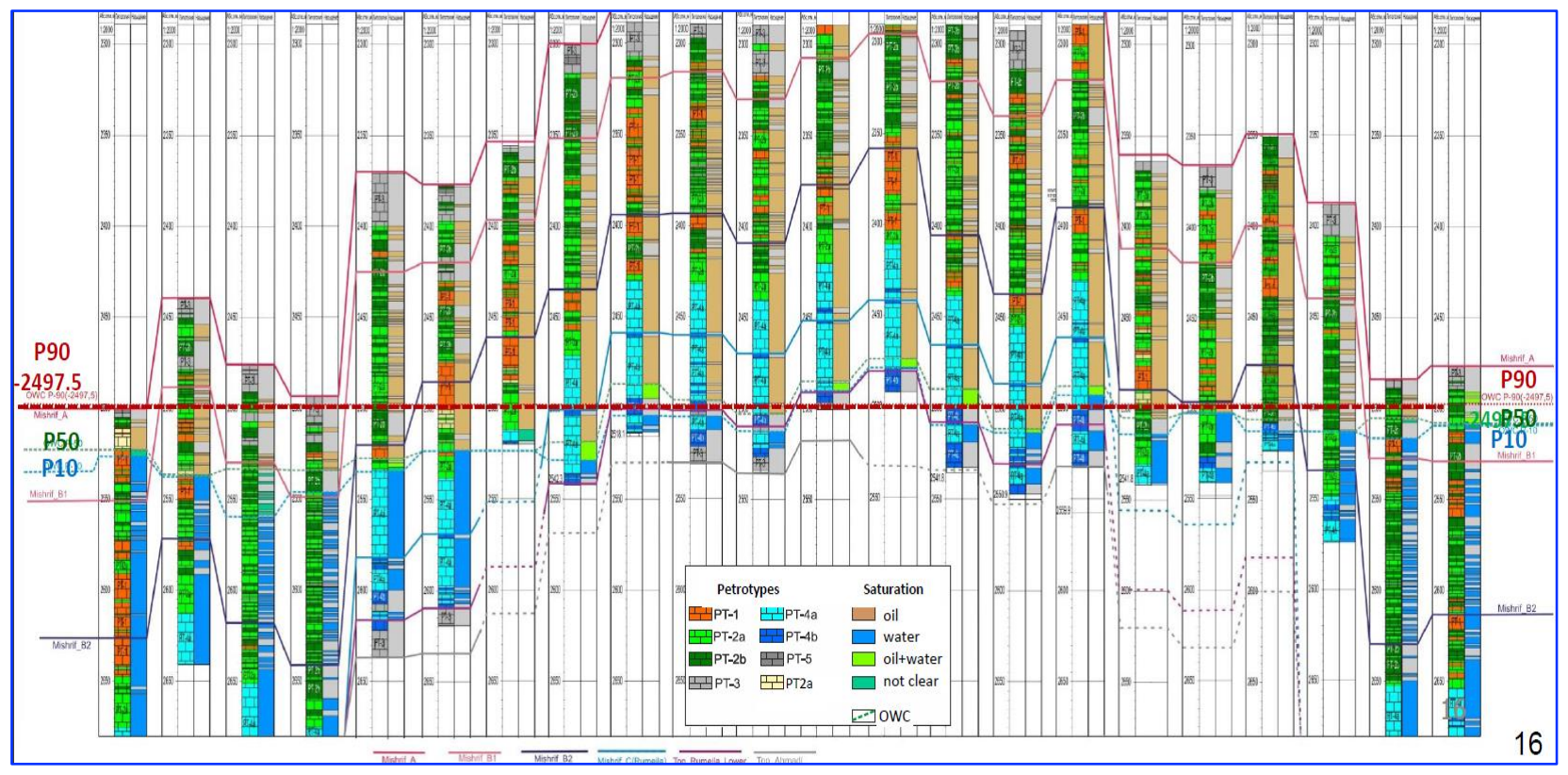

Fig. 18. Illustration of OWC levels considered for STOIIP calculations 


\subsection{Uncertainty Analysis}

The $\mathrm{P} 10$ is defined as the high case, there is a $90 \%$ possibility that volumes are lower than this case. The P90 is defined as the low case, there is a 90\% possibility that volumes are higher than this case. Also, the P50 is considered as an optimal case. P-10 includes all the oil initially in place; a non-horizontal OWC by the water top is adopted as per the logging data. P-50 includes the oil initially in place; a nonhorizontal OWC by the oil bottom is adopted as per the logging data. P-90 includes the oil initially in place; one horizontal OWC at the point of $-2497.5 \mathrm{~m}$ is adopted that corresponds to the upper point of the testing interval where the water inflow was produced. Volumetrics and STOIIP of the Mishrif formation as per P-10, P-50, P-90 cases are given in Table 2.

Table 2. The STOIIP calculations

\begin{tabular}{|c|c|c|c|c|}
\hline GM option & Bo (bbl /STB) & OWC level & Seed Sw & $\begin{array}{l}\text { STOIIP, } \\
\text { MMbbl }\end{array}$ \\
\hline P-90 & 1.21 & $\begin{array}{l}\text { Tilted OWC along the top of the } \\
\text { water level }\end{array}$ & 1526 & 16,231 \\
\hline P-50 & 1.22 & $\begin{array}{c}\text { Tilted OWC along the bottom of } \\
\text { the oil level }\end{array}$ & 5846 & 16,396 \\
\hline $\mathrm{P}-10$ & 1.23 & Horizontal OWC at $-2497.5 \mathrm{~m}$ & 6581 & 16,959 \\
\hline
\end{tabular}

\section{Conclusions}

The STOIIP of the Mishrif-Rumaila formations was calculated on the basis of the digital geological model by volumetric method and for different petrotypes. The STOIIP as of 01.07.2021 was estimated at $16396 \mathrm{MMbbl}$ on the whole for the Mishrif Formation in the selected oilfield. The importance of further development of this oilfield is validated by its very high STOIIP and this model is considered the first step to reservoir dynamic model construction and this is where the worth of this study becomes clear. After performing sensitivity and uncertainty analysis, OWC appeared to be the main uncertain parameter for STOIIP estimation because the available geological and field data was not enough to confidently prove it and only 21 wells have penetrated the water zone in the Mishrif formation out of 161 wells in total. The formation volume factor $\left(B_{0}\right)$ variable has a major influence, and SeedSw variable has a reasonable effect also compared to the rest of the variables. These three variables are taken into consideration in the uncertainty analysis due to the results of the tornado chart, while the SeedPHI and SeedN/G variables were excluded from the uncertainty analysis because of their very minor impact on the STOIIP calculations. STOIIP distribution for the formation is related mainly to logging data interpretation, the specification of petrophysical dependencies by core study data, and the drilling of production wells. Data on 161 wells and petrophysical studies allowed the determination of the in-place volumes with adequate accuracy. STOIIP of geological models P10 and P90 are 3.4\% higher and 1\% lower than those in model P50, respectively. Integration of seismic survey data is recommended to further improve the constructed geological model.

\section{Acknowledgements}

The authors would like to thank Schlumberger Company for providing the license to use the academic version of the PETREL platform and ECLIPSE simulator. The authors are very grateful to the Editor in Chief Prof. Dr. Salih M. Awadh, the Secretary of Journal Mr. Samir R. Hijab. and the Technical Editors for their great efforts and valuable comments. 


\section{References}

Abbas, L. K., Mahdi, T. A. 2020. Reservoir modeling of Mishrif Formation in Majnoon Oil Field, Southern Iraq. Iraqi Geological Journal, 53, 89-101.

Abeed, A. T., Lazim, S. A., Hamied, R. S., 2019. Modeling of petrophysical properties and reserve estimation of Mishrif Formation-Garraf Oil Field. IOP Conference Series: Materials Science and Engineering, 579, 012037.

Absalyamov, A. V., Bogachev, K. Y., Glazkova, E. A., Kostin, G. A., Telishev, A. S., Tregub, S. L., Shimonin, E. Y. 2020. Coupled static and dynamic high resolution modelling on high performance computer clusters. SPE Russian Petroleum Technology Conference, D043S021R002.

Al-Fatlawi, O. 2018. Numerical Simulation for the Reserve Estimation and Production Optimization from Tight Gas Reservoirs.

Al-Ali, M. M., Mahdi, M. M., Alali, R. A. 2019. Microfacies and depositional environment of Mishrif Formation, North Rumailaoilfielfd, Southern Iraq. Iraqi Geological Journal, 91-104.

Al-Fatlawi, O., Hossain, M. \& Essa, A. 2019a. Optimization of Fracture Parameters for Hydraulic Fractured Horizontal Well in a Heterogeneous Tight Reservoir: An Equivalent Homogeneous Modelling Approach.

Al-Fatlawi, O., Hossain, M., Patel, N. \& Kabir, A., 2019b. Evaluation of the Potentials for Adapting the Multistage Hydraulic Fracturing Technology in Tight Carbonate Reservoir. SPE Middle East Oil and Gas Show and Conference, D022S054R002.

Al-Fatlawi, O., Vimalroy, A. R., Hossain, M. M., Kabir, A. H., 2017. Optimization of infill drilling in whicher range field in Australia. SPE Kingdom of Saudi Arabia Annual Technical Symposium and Exhibition, D033S014R003.

Al-Mimar, H.S., Awadh, S.M., Al-Yaseri, A.A. and Yaseen, Z.M., 2018. Sedimentary units-layering system and depositional model of the carbonate Mishrif reservoir in Rumaila oilfield, Southern Iraq. Modeling Earth Systems and Environment, 4(4), 1449-1465.

Awadeesian, A.M., Al-Jawad, S.N., Awadh, S.M. and Al-Maliki, M.M., 2018. Chronostratigraphically based reservoir model for Cenomanian carbonates, southeastern Iraq oilfields. The Iraqi Geological Journal, 127.

Awadeesian, A.M., Awadh, S.M., Al-Dabbas, M.A., Al-Maliki, M.M., Al-Jawad, S.N. and Hussein, A.K.S., 2019. A modified water injection technique to improve oil recovery: Mishrif carbonate reservoirs in Southern Iraq oil fields, case study. The Iraqi Geological Journal, 125-146.

Awadh, S.M., Al-Mimar, H.S. and Al-Yaseri, A.A., 2018. Salinity mapping model and brine chemistry of Mishrif reservoir in Basrah oilfields, Southern Iraq. Arabian Journal of Geosciences, 11(18), 1-12.

Awadh, S.M., Al-Auweidy, M.R. and Al-Yaseri, A.A., 2019. Hydrochemistry as a tool for interpreting brine origin and chemical equilibrium in oilfields: Zubair reservoir southern Iraq case study. Applied Water Science, 9(3), 1-12.

Aziz, Q. A. A., \& Hussein, H. A., 2021. Mechanical rock properties estimation for carbonate reservoir using laboratory measurement: A case study from Jeribe, Khasib and Mishrif Formations in Fauqi Oil Field. The Iraqi Geological Journal, 88-102.

Bashore, W. M., Araktingi, U. G., Levy, M., Schweller, W. J. 1993. The importance of the geological model for reservoir characterization using geostatistical techniques and the impact on subsequent fluid flow. SPE Annual Technical Conference and Exhibition, SPE-26474-MS.

Boschetti, T., Awadh, S.M., Al-Mimar, H.S., Iacumin, P., Toscani, L., Selmo, E. and Yaseen, Z.M., 2020. Chemical and isotope composition of the oilfield brines from Mishrif Formation (southern Iraq): Diagenesis and geothermometry. Marine and Petroleum Geology, 122, p.104637.

Boukadi, F., Bemani, A., Rumhy, M. 1999. Effect of pvt properties variation with depth in hydrocarbon reservoirs. Petroleum Science and Technology, 17, 81-98.

Cavero, J., Orellana, N., Yemez, I., Singh, V., Izaguirre, E., 2016. Importance of conceptual geological models in 3D reservoir modelling. First Break, 34.

Chafeet, H. A., Handhal, A. M., \& Raheem, M. K. 2020. Microfacies and depositional analysis of the Mishrif Formation in selected wells of Ratawi Oilfield, Southren Iraq. The Iraqi Geological Journal, 127-153.

Coats, K. H. 1969. Use and misuse of reservoir simulation models. Journal of Petroleum Technology, 21, 13911398. 
Dheyauldeen, A., Al-Fatlawi, O., Hossain, M. M., 2021. Incremental and acceleration production estimation and their effect on optimization of well infill locations in tight gas reservoirs. Journal of Petroleum Exploration and Production Technology.

Farmer, C. 2005. Geological Modelling and Reservoir Simulation.

Irby, T. L. \& Arps, I. H. 1964. Application of computer technology to reservoir studies in Canada. Journal of Canadian Petroleum Technology, 3, 130-135.

Kamali, M. R., Omidvar, A., Kazemzadeh, E. 2013. 3D geostatistical modeling and uncertainty analysis in a carbonate reservoir, SW Iran. Journal of Geological Research, 687947.

Kantzas, A., Marentette, D. F., Erno, B. \& Harding, S. 1994. Characterization of a heavy oil reservoir using computer assisted tomography of core material. Journal of Canadian Petroleum Technology, 33.

Kimber, R. N., Curtis, M. D., Boundy, F. O., Diamond, P. H., Uwaga, A. O. 2016. Volumetric and dynamic uncertainty modelling in Block 22, offshore Trinidad and Tobago. 22, 21-36.

King, M. J., Mansfield, M., 1997. Flow Simulation of Geologic Models. SPE Annual Technical Conference and Exhibition, SPE-38877-MS

Kolmakov, A., Kilyakov, A., 2018. Design and development of relational geospatial database aimed at gathering and systematization of wide range of geological and geophysical data. SPE Russian Petroleum Technology Conference, D033S026R003.

León, A., Samaniego, F., Ascencio, F., Guevara, J. 1995. A study of the initial and explotation conditions of the super giant Akal offshore naturally fractured reservoir.

Lerat, O., Nivlet, P., Doligez, B., Lucet, N., Roggero, F., Berthet, P., Lefeuvre, F. \& Vittori, J., 2007. Construction of a Stochastic Geological Model Constrained by High-Resolution 3D Seismic Data, Application to the Girassol Field, Offshore Angola. SPE Annual Technical Conference and Exhibition, SPE-110422-MS.

Pumjan, S. \& Young, D. S. 1999. Geotecahnical site characterizations in localized probabilistic terms. Vail Rocks. The 37th U.S. Symposium on Rock Mechanics (USRMS), 1999. ARMA-99-0801.

Shaker, N., Al-Mayyahi, H. K., Al-Malikee, H. S., 2020. Variation of saturation pressure values in Mishrif And Zubair ReservoirS in Rumaila Oilfield, Southern Iraq. The Iraqi Geological Journal, 16-31.

Witter, J. B., Siler, D. L., Faulds, J. E. \& Hinz, N. H. 2016. 3D geophysical inversion modeling of gravity data to test the 3D geologic model of the Bradys geothermal area, Nevada, USA. Geothermal Energy, 4, 14. 